\section{High Storage Humidity Affects Fruit Quality Attributes and Incidence of Fruit Cracking in Cold-stored 'Royal Gala' Apples}

\author{
Jinwook Lee ${ }^{1}$ \\ Department of Integrative Plant Science, Chung-Ang University, Anseong, \\ Gyeonggi-do, 17546, Republic of Korea
}

James P. Mattheis and David R. Rudell

USDA-ARS, Tree Fruit Research Laboratory, 1104 North Western Avenue, Wenatchee, WA 98801

Additional index words. Malus domestica Borkh., cold storage, shriveling, cracking, flesh breakdown

\begin{abstract}
Royal Gala' apples can be susceptible to the incidence of fruit cracking and senescent flesh breakdown during cold storage. Because the development of these physiological disorders in other cultivars can be influenced by humidity during storage, the objective of this study was to evaluate the effect of high storage humidity on fruit quality attributes and incidence of physiological disorders in cold-stored 'Royal Gala' apples. Fruit obtained from a commercial orchard were kept in cardboard boxes with or without a perforated polyethylene liner during and after cold storage. High storage humidity induced by the perforated polyethylene liner reduced fresh weight loss but enhanced the change of fruit circumference after cold storage. High storage humidity contributed the most reduction of cortex lightness $\left(L^{*}\right)$ and hue angle $\left(h^{\circ}\right)$ in stem-end cortex tissues during shelf life. Fruit stored with liners had reduced internal ethylene concentration (IEC) and outer cortex firmness after removal from storage compared with control fruit. Furthermore, high storage humidity prevented shriveling but provoked fruit cracking. The incidence and severity of flesh breakdown were further aggravated during shelf life, compared with cold storage, regardless of a liner application. Overall, maintaining high storage humidity by applying a perforated polyethylene liner can contribute to delaying fresh weight loss, reducing IEC, and preventing fruit shriveling but can enhance cortex tissue browning, loss of flesh firmness, and incidence of fruit cracking during cold storage and shelf life.
\end{abstract}

'Gala' apple strains are susceptible to stem-end fruit cracking at harvest (Fallahi et al., 2013) and during storage (Lee et al., 2013, 2016). The incidence of stem-end fruit cracking at harvest is influenced by several factors such as rootstock (Fallahi et al., 2013), irrigation (Opara et al., 2000), nutrient management (Opara et al., 1997b; Perring, 1984), and fruit maturity (Byers, 1998; Opara et al., 1997b). During and after cold storage, fruit size positively contributes to increases in fruit circumference, thereby inducing fruit cracking (Lee et al., 2013). Stem-end splitting during storage also increases with advanced fruit maturity at harvest in cold-stored 'Honeycrisp' apples (Wargo and Watkins, 2004). 'Royal Gala' cracking incidence and severity increase with increased storage

Received for publication 19 July 2018. Accepted for publication 27 Aug. 2018.

Financial support for this research was received from AgroFresh, Inc.

We thank David Buchanan, Janie Countryman, Rachel Leisso, Brenda Steady, and Karen Blaedow for excellent technical assistance.

${ }^{1}$ Corresponding author. E-mail: JL425@cau.ac.kr.
In terms of fruit physiological disorders, cracking was expressed as fractures in the cuticle or skin which would be microscopic or easily seen, sometimes extending deep into the inner flesh. Splitting was defined as an extreme phenotype of cracking which would penetrate deep into the flesh (Opara et al., 1997a). Although there was a terminological definition on the difference between cracking and splitting based on the developmental mechanism of the physiological disorders (Opara et al., 1997a), it seems like that splitting would be a part of cracking incidence in general.

High storage humidity slows the loss of fruit fresh weight, accumulation of soluble solids, and firmness loss and delays ripening of plantain bananas (Thompson et al., 1974). The decrease in apple fruit cortex tissue stiffness and weight loss are less in fruit stored in high humidity ( $\mathrm{Tu}$ et al., 2000). Higher storage humidity results in less fruit weight loss and higher fruit firmness in CAstored 'McIntosh' apples compared with low humidity (Lidster, 1990). Fruit ripening in terms of peel color change and flesh firmness loss is delayed during storage in a microperforated polyethylene film at $1{ }^{\circ} \mathrm{C}$, compared with $3{ }^{\circ} \mathrm{C}$ (Watkins and Thompson, 1992).

The increase in relative humidity caused by exposing the surface of the epidermal segments to water increases the number of microcracks in apple fruits (Knoche and Grimm, 2008). Water vapor permeance is also positively linked to cuticular microcracking incidence in 'Braeburn' apples (Maguire et al., 1999). Fruit surface wetness enhances incidence and severity of skin spot and microcracking in 'Elstar' apple fruit before harvest and during storage (Winkler et al., 2014). The pattern of microcrack formation in the fruit cuticle of epidermal segments showed a wide range of physical responses to water exposure in several apple cultivars (Knoche and Grimm, 2008). Microperforated polyethylene bag results in provoking more superficial scald incidence in cold-stored 'Cox's Orange Pippin' apples, compared with unbagged fruit or commercial polybags with larger perforation size (Watkins and Thompson, 1992). Although it is known that high storage humidity can play a crucial role in maintaining fruit quality by delaying fruit fresh weight loss and the reduction of flesh firmness, thereby retaining fruit freshness longer, higher storage humidity can consequently contribute to provoking the incidence of fruit cracking and internal physiological disorders, including flesh breakdown.

Commercial reports of cracking in 'Gala' apples during storage indicated that symptoms were aggravated during shelf life when packed apple cartons are tightly sealed with a plastic film. In our previous studies, 'Royal Gala' fruit were stored inside a polyethylene liner in a cardboard box during cold storage and shelf life (Lee et al., 2013, 2016). These studies led to the hypothesis that the polyethylene liner alone impacts incidence of 
physiological disorders in 'Royal Gala' apple fruit during cold storage and shelf life. Therefore, the objective of this study was to evaluate the effects of the perforated polyethylene liner, which maintains higher humidity during storage and shelf life, on fruit quality attributes and the incidence of physiological disorders, including shriveling, cracking, and flesh breakdown, in coldstored 'Royal Gala' apples.

\section{Materials and Methods}

Plant material and fruit storage. 'Royal Gala' apples (Malus $\times$ domestica Borkh.) harvested from mature trees in a commercial orchard near Vantage, WA were transported to a laboratory in Wenatchee, WA. Fruit without external blemishes that weighed more than $230 \mathrm{~g}$ were placed on pressed fiber trays (18 fruit/tray) and packed with or without a perforated polyethylene liner (polyliner) in cardboard boxes. Polyliner dimensions were $521 \mathrm{~mm}$ length, $330 \mathrm{~mm}$ width, and $762 \mathrm{~mm}$ depth with $5 \mathrm{~mm}$ hole diameter. Each liner had 16 holes, eight on each long side in two rows of four. Holes were $130 \mathrm{~mm}$ apart, and they were located starting $90 \mathrm{~mm}$ from the bag bottom and bag side. All fruit were stored in air at $0.5^{\circ} \mathrm{C}$ in a cold room with $\approx 90 \%$ relative humidity (RH) for 6 months, followed by $20^{\circ} \mathrm{C}$ in a room with $60 \pm 10 \% \mathrm{RH}$ for $7 \mathrm{~d}$. The $\mathrm{RH}$ and temperature were recorded using a Veriteq Spectrum SP-2000-2OR humidity and temperature sensor (Vaisala Canada Inc., Richmond, B.C., Canada).

Fruit quality assessment. Fruit fresh weight and circumference were measured with an analytical balance and a tape measure, respectively. Measurements were conducted at harvest and after storage on the same fruit. Peel color variables on an unblushed area of the fruit equator region were measured with a chromameter (Minolta CR-200; Minolta Co., Osaka, Japan). Flesh color was assessed at the stem-end $(1.5 \mathrm{~cm}$ from the stem-end toward the equator, cut horizontally), equator (at the fruit equator, cut horizontally), and the calyx-end $(1.5 \mathrm{~cm}$

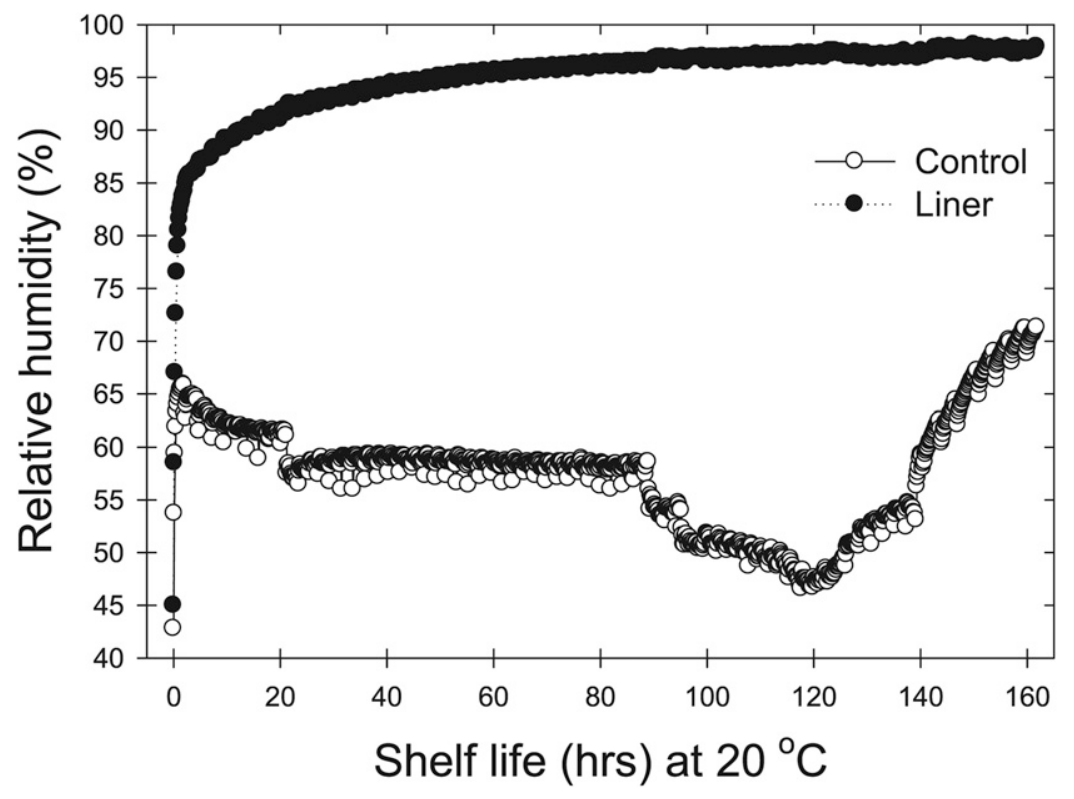

Fig. 1. Relative humidity of 'Royal Gala' apple fruit stored without (Control) or with a perforated polyethylene liner during a 7 -d shelf life at $20{ }^{\circ} \mathrm{C}$ after 6 months of cold storage in air at $0.5^{\circ} \mathrm{C}$. Each carton box had 36 apple fruit.

from the calyx-end toward the equator, cut horizontally), with six readings per region using the same chromameter. Color measurements were expressed as lightness $\left(L^{*}, 0-\right.$ $100)$, chroma $\left(C^{*}\right)$, and hue angle $\left(h^{\circ}, 0-360\right)$ (McGuire, 1992).

Internal ethylene concentration (IEC) was measured by withdrawing a $0.5-\mathrm{mL}$ gas sample from the core cavity using a syringe and analyzing the sample using a HewlettPackard 5880A gas chromatograph (HewlettPackard, Palo Alto, CA) equipped with a flame ionization detector and 46-cm (length) $\times$ $0.32-\mathrm{cm}$ (diameter) glass column packed with Porapack Q (Supelco Co., Bellefonte, PA). Flow rates for $\mathrm{N}_{2}$ carrier, $\mathrm{H}_{2}$, and air were $0.5,0.17$, and $3.3 \mathrm{~mL} \cdot \mathrm{s}^{-1}$, respectively. Oven, injector, and detector temperatures were 60 , 100 , and $200{ }^{\circ} \mathrm{C}$, respectively.

The $\mathrm{CO}_{2}$ production rate was determined using three replicates of four fruit placed into 3.79-L glass jars sealed with Teflon lids with two gas ports. Jars were purged with air at 1.7 $\mathrm{mL} \cdot \mathrm{s}^{-1}$ for $1 \mathrm{~h}$; then, $3 \mathrm{~mL}$ of head space gas collected from the lid outlet port was used for the $\mathrm{CO}_{2}$ analysis with a Hewlett Packard 5890 gas chromatograph (Agilent, Palo Alto, CA) equipped with a $0.5-\mathrm{m}, 3.2-\mathrm{mm}$ i.d., stainless steel column packed with Porapak Q (Supelco), a methanizer (John Booker \& Co., Austin, TX), and a flame ionization detector. The $\mathrm{N}_{2}$ carrier, $\mathrm{H}_{2}$, and air flow rates were $0.5,0.5$, and $5 \mathrm{~mL} \cdot \mathrm{s}^{-1}$, respectively. Oven and injector temperatures were 35 and $300{ }^{\circ} \mathrm{C}$, respectively. The methanizer temperature was $290{ }^{\circ} \mathrm{C}$ and was controlled by an instrumentation temperature controller (Valco Instruments Inc., Houston, TX) with an $\mathrm{H}_{2}$ flow of $0.5 \mathrm{~mL} \cdot \mathrm{s}^{-1}$.

Flesh firmness, tissue tensile strength (TTS), and crispness were assessed using a penetrometer (Mohr Digi-Test; Mohr \& Associates, Richland, WA) equipped with a cylindrical plunger $11 \mathrm{~mm}$ in diameter. Measurements were performed on two pared surfaces on opposite sides of the fruit equator region. Maximum cortex firmness of the outer $8 \mathrm{~mm}$ (outer cortex, M1) and $8 \mathrm{~mm}$ from the core line boundary (inner cortex, M2), TTS at $8 \mathrm{~mm}$, and crispness were assessed (Mattheis, 2017). TTS indicated the relaxation rate of the fruit with $4.54 \mathrm{~kg}$ of creep force for $0.5 \mathrm{~s}$ at the boundary between regions from the outer $8 \mathrm{~mm}$ and

Table 1. Fresh weight loss ( $\Delta$ fresh wt), fruit circumference change ( $\Delta$ fruit circumference), and peel color changes in terms of lightness $\left(L^{*}\right)$, chroma $\left(C^{*}\right)$, and hue angle $\left(h^{\circ}\right)$ of 'Royal Gala' apple fruit stored in air at $0.5^{\circ} \mathrm{C}$ for 6 mo. followed by $7 \mathrm{~d}$ at $20^{\circ} \mathrm{C}$.

\begin{tabular}{|c|c|c|c|c|c|c|c|c|c|c|}
\hline \multirow[b]{2}{*}{ Storage duration } & \multicolumn{2}{|c|}{ 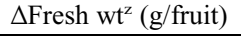 } & \multicolumn{2}{|c|}{$\Delta$ Circumference $^{\mathrm{z}}$ (mm/fruit) } & \multicolumn{2}{|c|}{ Peel lightness $\left(L^{*}\right)$} & \multicolumn{2}{|c|}{ Peel chroma $\left(C^{*}\right)$} & \multicolumn{2}{|c|}{ Peel hue angle $\left(h^{\circ}\right)$} \\
\hline & Control & Liner & Control & Liner & Control & Liner & Control & Liner & Control & Liner \\
\hline $0 \mathrm{mo}$ & - & - & - & - & $75.3^{x}$ & - & 28.1 & - & 84.7 & - \\
\hline 6 mo. $+0 \mathrm{~d}$ & $18.9^{\mathrm{y}}$ & 6.4 & 6.9 & 0.8 & 55.8 & 60.9 & 34.7 & 34.8 & 45.3 & 53.9 \\
\hline $6 \mathrm{mo.}+7 \mathrm{~d}$ & 22.5 & 8.6 & 4.8 & -2.9 & 57.5 & 59.3 & 36.5 & 37.3 & 50.8 & 51.9 \\
\hline Source & \multicolumn{2}{|c|}{$\Delta$ Fresh weight } & \multicolumn{2}{|c|}{$\Delta$ Circumference } & \multicolumn{2}{|c|}{ Peel lightness } & \multicolumn{2}{|c|}{ Peel chroma } & \multicolumn{2}{|c|}{ Peel hue angle } \\
\hline Liner (L) & \multicolumn{2}{|c|}{$* * * *$} & \multicolumn{2}{|c|}{$* * * *$} & \multicolumn{2}{|c|}{$* *$} & \multicolumn{2}{|c|}{ NS } & \multicolumn{2}{|c|}{ NS } \\
\hline Duration (D) & \multicolumn{2}{|c|}{$* * * *$} & \multicolumn{2}{|c|}{$* * * *$} & \multicolumn{2}{|c|}{$* * * *$} & \multicolumn{2}{|c|}{$* *$} & \multicolumn{2}{|c|}{$* * * *$} \\
\hline $\mathrm{L} \times \mathrm{D}$ & \multicolumn{2}{|c|}{ NS } & \multicolumn{2}{|c|}{ NS } & \multicolumn{2}{|c|}{ NS } & \multicolumn{2}{|c|}{ NS } & \multicolumn{2}{|c|}{ NS } \\
\hline
\end{tabular}

${ }^{\mathrm{z}}$ Fruit fresh weight and circumference difference $=$ harvest value - poststorage (or after 7-d shelf life) value $(n=18)$.

${ }^{\mathrm{y}}$ Values are means $(n=18)$.

${ }^{\mathrm{x}}$ Values of color parameters are means $(n=18)$, with three readings per replicate.

Ns $, * *, * * * *$ Nonsignificant or significant at $P<0.01$ or 0.0001 , respectively. 
$8 \mathrm{~mm}$ from the core line boundary. TTS and crispness values were recorded as $\mathrm{Co}$ and $\mathrm{Cn}$, respectively, as Mohr Digi-test data. Starch pattern index was estimated by cutting each fruit horizontally through the equator and then staining the cut surface using a potassium-iodine $(1.5 \% \mathrm{KI}, 0.6 \% \mathrm{I})$ solution. Starch pattern index from 1 (100\% starch) to $6(0 \%$ starch $)$ was determined using the scale described by Brookfield et al. (1997).

Fruit index of absorbance difference $\left(I_{\mathrm{AD}}\right)$ was determined using a DA meter (53500 DA meter; T.R. Turono srl, Forli, Italy). $I_{\mathrm{AD}}$ on the fruit blush and shade sides was used to calculate the overall mean for each fruit (Costamagna et al., 2013). Soluble solids concentration (SSC) and titratable acidity (TA) in freshly prepared juice extracted from composite samples of two segments per two fruit were determined using a refractometer (Atago N1; Atago Co. Ltd., Tokyo, Japan) and autotitrator (TIM850, SAC80; Hach Co., Loveland, CO), respectively. TA was determined by titrating juice with $0.1 \mathrm{M} \mathrm{KOH}$ to $\mathrm{pH} 8.1$.

Incidence and severity of peel shriveling and cracking were recorded and then fruit were horizontally sliced into five or six sections. Incidence and severity of flesh breakdown were assessed. Disorder incidence was expressed as percent fruit affected $(n=18)$. The severity of external and internal physiological disorders was subjectively scored from 0 to $6(0=0 \%, 1=1 \%$ to $10 \%, 2=11 \%$ to $25 \%, 3=26 \%$ to $50 \%, 4=$ $51 \%$ to $75 \%$, and $5=76 \%$ to $100 \%$ of the area of the peel or the slice with the largest area with cracking and breakdown) (Lee et al., 2013).

\section{Experimental Design and Statistical Analysis}

Statistical analyses. The experiment was conducted with the presence or absence of a perforated polyethylene liner during cold storage and shelf life. Fruit quality attributes and incidence and severity of physiological disorders were analyzed according to a completely randomized experimental design. To assess fruit quality attributes and physiological disorders, 18 fruit per treatment were used, with three replicates of six fruit each. All statistical analyses were performed with SAS version 9.3 (SAS Institute Inc., Cary, NC). Analysis of variance (ANOVA) using the general linear model (GLM) procedure was used to determine the main and interaction effects, and Duncan's multiple range test was used to determine the mean separation. Pearson correlation coefficient analysis (PROC CORR) was performed to identify relationships between response variables, fruit quality, and storage disorders.

\section{Results}

Cold room RH was not monitored during storage. During shelf life, the RH fluctuated between 46 and $72 \%$ in the $20{ }^{\circ} \mathrm{C}$ room in which fruit were kept (Fig. 1). RH inside the polyliner during this period rapidly increased and was more than $90 \%$ for most of the shelf life.

Table 2. Cortex tissue color variables $\left(L^{*}, C^{*}\right.$, and $\left.h^{\circ}\right)$ of stem-end, equator, and calyx-end internal tissues of 'Royal Gala' apple fruit stored in air at $0.5^{\circ} \mathrm{C}$ for 6 mo. followed by $7 \mathrm{~d}$ at $20^{\circ} \mathrm{C}$.

\begin{tabular}{|c|c|c|c|c|c|c|}
\hline \multirow[b]{2}{*}{ Storage duration } & \multicolumn{2}{|c|}{ Stem-end } & \multicolumn{2}{|c|}{ Equator } & \multicolumn{2}{|c|}{ Calyx-end } \\
\hline & Control & $\overline{\text { Liner }}$ & Control & $\overline{\text { Liner }}$ & Control & Liner \\
\hline & \multicolumn{6}{|c|}{ Lightness $\left(L^{*}\right)$} \\
\hline 0 mo. & $82.1^{z}$ & - & 83.6 & - & 82.6 & - \\
\hline $6 \mathrm{mo.}+0 \mathrm{~d}$ & 80.6 & 80.9 & 82.3 & 82.9 & 80.4 & 80.6 \\
\hline \multirow[t]{2}{*}{6 mo. $+7 d$} & 77.7 & 76.1 & 80.5 & 80.9 & 79.5 & 78.6 \\
\hline & \multicolumn{6}{|c|}{ Chroma $\left(C^{*}\right)$} \\
\hline 0 mo. & 20.9 & - & 16.7 & - & 15.6 & - \\
\hline $6 \mathrm{mo.}+0 \mathrm{~d}$ & 21.5 & 22.6 & 18.5 & 18.9 & 20.4 & 21.7 \\
\hline \multirow[t]{2}{*}{$6 \mathrm{mo.}+7 \mathrm{~d}$} & 23.9 & 24.6 & 20.3 & 20.5 & 22.5 & 24.0 \\
\hline & \multicolumn{6}{|c|}{ Hue angle $\left(h^{\mathrm{o}}\right)$} \\
\hline 0 mo. & 104.4 & - & 105.9 & - & 106.8 & - \\
\hline $6 \mathrm{mo.}+0 \mathrm{~d}$ & 100.5 & 100.2 & 102.8 & 102.8 & 103.3 & 102.8 \\
\hline $6 \mathrm{mo.}+7 \mathrm{~d}$ & 95.5 & 93.7 & 99.5 & 98.4 & 100.0 & 97.9 \\
\hline Source & \multicolumn{2}{|c|}{ Lightness $\left(L^{*}\right)$} & \multicolumn{2}{|c|}{ Chroma $\left(C^{*}\right)$} & \multicolumn{2}{|c|}{ Hue angle $\left(h^{\circ}\right)$} \\
\hline Liner (L) & \multicolumn{2}{|c|}{ NS } & \multicolumn{2}{|c|}{$* * *$} & \multicolumn{2}{|c|}{$* *$} \\
\hline Duration (D) & \multicolumn{2}{|c|}{$* * * *$} & \multicolumn{2}{|c|}{$* * * *$} & \multicolumn{2}{|c|}{$* * * *$} \\
\hline Tissue $(\mathrm{T})$ & \multicolumn{2}{|c|}{$* * * *$} & \multicolumn{2}{|c|}{$* * * *$} & \multicolumn{2}{|c|}{$* * * *$} \\
\hline $\mathrm{L} \times \mathrm{D}$ & \multicolumn{2}{|c|}{$*$} & \multicolumn{2}{|c|}{ NS } & \multicolumn{2}{|c|}{$*$} \\
\hline $\mathrm{L} \times \mathrm{T}$ & \multicolumn{2}{|c|}{ NS } & \multicolumn{2}{|c|}{ NS } & \multicolumn{2}{|c|}{ NS } \\
\hline $\mathrm{D} \times \mathrm{T}$ & \multicolumn{2}{|c|}{$* *$} & \multicolumn{2}{|c|}{$* * * *$} & \multicolumn{2}{|c|}{ NS } \\
\hline $\mathrm{L} \times \mathrm{D} \times \mathrm{T}$ & \multicolumn{2}{|c|}{ NS } & \multicolumn{2}{|c|}{ NS } & \multicolumn{2}{|c|}{ NS } \\
\hline
\end{tabular}

${ }^{\mathrm{z}}$ Values of color parameters are means of 18 replicates $(n=18)$ with three readings per replicate.

NS $, *, * *, * * *, * * * *$ Nonsignificant or significant at $P<0.05,0.01,0.001$, or 0.0001 , respectively.

Table 3. Internal ethylene concentration (IEC), $\mathrm{CO}_{2}$ production, and $I_{\mathrm{AD}}$ of 'Royal Gala' apple fruit stored in air at $0.5^{\circ} \mathrm{C}$ for $6 \mathrm{mo}$. followed by $7 \mathrm{~d}$ at $20^{\circ} \mathrm{C}$.

\begin{tabular}{|c|c|c|c|c|c|c|}
\hline \multirow[b]{2}{*}{ Storage duration } & \multicolumn{2}{|c|}{$\operatorname{IEC}\left(\mu \mathrm{L} \cdot \mathrm{L}^{-1}\right)$} & \multicolumn{2}{|c|}{$\mathrm{CO}_{2}$ production $\left(\mu \mathrm{mol} \mathrm{CO} 2 / \mathrm{kg} \cdot \mathrm{h}^{-1}\right)$} & \multicolumn{2}{|c|}{$I_{\mathrm{AD}}\left(\mathrm{A}_{670}-\mathrm{A}_{720}\right)$} \\
\hline & $\overline{\text { Control }}$ & Liner & Control & Liner & Control & Liner \\
\hline $0 \mathrm{mo}$. & $1.0^{z} \mathrm{c}^{\mathrm{x}}$ & - & - & - & - & - \\
\hline $6 \mathrm{mo} .+0 \mathrm{~d}$ & $11.6 \mathrm{bc}$ & $15.3 \mathrm{~b}$ & $303.3^{\mathrm{y}}$ & 317.9 & 0.06 & 0.06 \\
\hline $6 \mathrm{mo} .+7 \mathrm{~d}$ & $162.8 \mathrm{a}$ & $17.7 \mathrm{~b}$ & 507.4 & 490.8 & 0.04 & 0.05 \\
\hline Source & \multicolumn{2}{|c|}{ IEC } & \multirow{2}{*}{\multicolumn{2}{|c|}{$\mathrm{CO}_{2}$ production }} & \multicolumn{2}{|c|}{$I_{\mathrm{AD}}$} \\
\hline Liner (L) & \multirow{2}{*}{\multicolumn{2}{|c|}{$\begin{array}{l}* * * * \\
* * * *\end{array}$}} & & & & \\
\hline Duration (D) & & & \multicolumn{2}{|c|}{$* * * *$} & \multicolumn{2}{|c|}{ NS } \\
\hline $\mathrm{L} \times \mathrm{D}$ & \multicolumn{2}{|c|}{$* * * *$} & \multicolumn{2}{|c|}{ NS } & \multicolumn{2}{|c|}{ NS } \\
\hline
\end{tabular}

${ }^{\mathrm{z}}$ Values are means $(n=18)$.

${ }^{\mathrm{y}}$ Values are means $(n=6)$ of four fruit.

${ }^{\mathrm{x}}$ Means of each category followed by the same letters do not differ significantly. Duncan's multiple range test at $P \leq 0.05$.

NS $, * *, * * *$ Nonsignificant or significant at $P<0.01$ or 0.0001 , respectively.

Table 4. Outer cortex firmness (M1), inner cortex firmness (M2), tissue tensile strength (TTS), and crispness of 'Royal Gala' apple fruit stored in air at $0.5^{\circ} \mathrm{C}$ for 6 mo. followed by $7 \mathrm{~d}$ at $20^{\circ} \mathrm{C}$.

\begin{tabular}{|c|c|c|c|c|c|c|c|c|}
\hline \multirow[b]{2}{*}{ Storage duration } & \multicolumn{2}{|c|}{ Firmness M1 (N) } & \multicolumn{2}{|c|}{ Firmness M2 (N) } & \multicolumn{2}{|c|}{ TTS $(\mathrm{cm})$} & \multicolumn{2}{|c|}{ Crispness } \\
\hline & Control & Liner & Control & Liner & Control & Liner & Control & Liner \\
\hline $0 \mathrm{mo}$ & $79.3^{z}$ & - & 105.5 & - & $0.000^{\mathrm{y}}$ & - & 182.9 & - \\
\hline $6 \mathrm{mo.}+0 \mathrm{~d}$ & 61.4 & 51.7 & 52.6 & 57.7 & 0.097 & 0.106 & 121.5 & 192.7 \\
\hline 6 mo. $+7 d$ & 43.8 & 33.9 & 42.4 & 42.8 & 0.235 & 0.259 & 114.4 & 126.2 \\
\hline Source & \multicolumn{2}{|c|}{ Firmness M1 } & \multicolumn{2}{|c|}{ Firmness M2 } & \multicolumn{2}{|c|}{ Strength } & \multicolumn{2}{|c|}{ Crispness } \\
\hline Liner (L) & \multicolumn{2}{|c|}{$* * * *$} & \multicolumn{2}{|c|}{$*$} & \multicolumn{2}{|c|}{ NS } & \multicolumn{2}{|c|}{$* *$} \\
\hline Duration (D) & \multicolumn{2}{|c|}{$* * * *$} & \multicolumn{2}{|c|}{$* * * *$} & \multicolumn{2}{|c|}{$* * * *$} & \multicolumn{2}{|c|}{$* *$} \\
\hline $\mathrm{L} \times \mathrm{D}$ & \multicolumn{2}{|c|}{ NS } & \multicolumn{2}{|c|}{ NS } & \multicolumn{2}{|c|}{ NS } & \multicolumn{2}{|c|}{ NS } \\
\hline
\end{tabular}

${ }^{\mathrm{z}}$ Values are means $(n=18)$.

${ }^{\mathrm{y}}$ Minimum detection limit $=0.003 \mathrm{~mm}$.

Outer cortex firmness (M1) measured in the cortex region from the pared surface to $8 \mathrm{~mm}$. Inner cortex firmness (M2) measured in the cortex region from $8 \mathrm{~mm}$ to the core line. Tissue tensile strength (TTS) deflection at $8 \mathrm{~mm}$ depth in the fruit.

NS $, *, * *, * * *$ Nonsignificant or significant at $P<0.05,0.01$, or 0.0001 , respectively.

Fruit fresh weight loss and decreased circumference during cold storage and shelf life were highest for controls (Table 1). Liner fruit circumference actually increased during shelf life. Peel $L^{*}$ was highest for liner fruit at removal from cold storage but similar for controls and liner fruit after shelf life. Peel $C^{*}$ and $h^{\circ}$ increased during cold storage and shelf life regardless of liner use. Liner $\times$ storage duration was not significant for any of these variables.

Fruit cortex $L^{*}$ was highest in equator tissue, irrespective of liner use (Table 2). Cortex $L^{*}$ values decreased during cold 
storage and shelf life, regardless of tissue or liner use. Cortex $L^{*}$ decreased most at the stem end in liner fruit. Cortex $C^{*}$ values increased during cold storage and shelf life. Flesh $h^{\circ}$ decreased during cold storage and shelf life and with liner use. The reduction in flesh $h^{\circ}$ was higher at the stem-end, compared with calyx-end tissue.

IEC was higher relative to harvest after storage and shelf life, but fruit stored in liners had lower values, compared with controls (Table 3). $\mathrm{CO}_{2}$ production increased during shelf life but was not influenced by liner. $I_{\mathrm{AD}}$ was not influenced by shelf life or liner.

Outer cortex firmness (M1) decreased during cold storage and shelf life, with the lowest values found for liner fruit (Table 4). Inner cortex firmness (M2) also decreased during cold storage and shelf life, but liner fruit had higher M2 compared with controls at the time of removal from cold storage. TTS decreased (increased values) during cold storage and shelf life but were unaffected by liner. Fruit crispness decreased during cold storage and shelf life but liner storage decreased crispness loss.

Incidence and severity of fruit shriveling occurred only on controls (Table 5). Cracking only occurred on liner fruit and incidence and severity increased during shelf life. Incidence and severity of flesh breakdown increased during shelf life with no influence of liner.

Correlations between variables for fruit quality attributes and physiological disorders were in general low. Nonetheless, there were 87 positive and 79 negative correlations for control fruit, while liner fruit had 105 positive and 111 negative correlations (Fig. 2). IEC was highly correlated with peel and flesh color, fruit fresh weight loss, and incidence and severity of senescent breakdown in control fruit but not in liner fruit. Fruit fresh weight loss was positively correlated with fresh weight and circumference at harvest, IEC, fruit circumference change, and incidence and severity of shriveling in control fruit but more diversely correlated with peel and cortex tissue color variables, along with the incidence and severity of storage disorders in liner fruit. In liner fruit, peel $L^{*}$ was negatively correlated with fresh weight loss, $I_{\mathrm{AD}}$, and the incidence and severity of senescent breakdown. Peel $h^{\circ}$ was positively correlated with IEC and peel $L^{*}$ but negatively with $I_{\mathrm{AD}}$ in control fruit. In contrast, peel $h^{\circ}$ was positively correlated with peel $L^{*}$, stemend cortex tissue $L^{*}$, calyx-end cortex tissue $L^{*}$, and stem-end cortex tissue $h^{\circ}$ but negatively with $I_{\mathrm{AD}}$ and the incidence and severity of senescent breakdown in liner fruit.

\section{Discussion}

This study revealed that high humidity resulting from packing 'Royal Gala' apples in a perforated polyethylene liner can prevent shriveling but enhance cracking during and after cold storage. Apples stored in high humidity have reduced transpiration (Prange et al., 2001), reduced fruit fresh weight during (Lidster, 1990) and after cold storage (Tu et al., 2000). Modified atmosphere (MA) bags reduce fresh weight loss in sweet cherry fruit during cold storage (Padilla-Zakour et al., 2004) but enhance cracking development (Padilla-Zakour et al., 2004). Cracking development may be related to the number of microcracks on the fruit outer epidermal surface that increase in high humidity (Knoche and Peschel, 2006). Accordingly, it is assumed that higher storage humidity during apple cold storage due to a perforated polyethylene liner should affect physiological and physical properties of apple peel and cortex tissues during cold storage and shelf life in terms of fresh weight loss and cracking incidence, respectively. On the other hand, high storage humidity might contribute to reduced peel epicuticular wax thereby provoking fruit cracking during cold storage, as shown by the microscopic cracking of sweet cherry fruit cuticle (Knoche and Peschel, 2006). Furthermore, fruit ripening and senescence would be another factor to be considered for the development of fruit cracking during storage and shelf life because fruit cracking incidence increases with increased storage duration (Lee et al., 2013). However, fruit ripening and softening during cold storage and shelf life are strongly associated with the activation of cell wall solubilization, which is linked to the upregulation of numerous cell wall degradation enzymes (Harb et al., 2012; Róth et al., 2005). Therefore, cell wall loosening in long-term cold stored apples might be involved in provoking the development of fruit cracking under high storage humidity.
'Royal Gala' apples are susceptible to flesh breakdown during cold storage (Lee et al., 2013; Lee et al., 2016). In this study, higher storage humidity did not influence flesh breakdown during or after cold storage. However, the incidence and severity of flesh breakdown increased during shelf life, regardless of a liner application. Incidence of apple fruit internal disorders has been linked to storage humidity and temperature (Weber et al., 2012). Fruit ripening and senescence progress during long-term cold storage and subsequent warm temperature shelf life illustrated here in part by increased IEC and respiration. Although IEC was lower at the end of the shelf life period in liner fruit, compared with controls, flesh breakdown was not impacted by liner use. This result may indicate that metabolic events leading to flesh breakdown had occurred before fruit removal from cold storage; therefore, a higher incidence after the shelf life was not related to the poststorage IEC.

Physiological responses of fruit quality attributes to storage humidity were highly divergent, depending on fruit physiological characteristics. In this study, high storage humidity by using a liner application resulted in reduced fresh weight loss, delayed decline in peel $L^{*}$ and flesh crispness, and suppressed increase in IEC after storage. However, the liner resulted in enhanced fruit circumference change and firmness loss. High storage humidity contributes to delaying fresh weight loss (Tu et al., 2000). The alteration of fruit firmness was greater in high humidity in several 'Gala' apple strains (Weber et al., 2012). Furthermore, storage humidity may not be involved in $\mathrm{CO}_{2}$ production and peel $C^{*}$ responses, but shelf life affected those. Peel $h^{\circ}$ and $I_{\mathrm{AD}}$ were unaffected by liner use nor by shelf life. The results indicate that the divergence of fruit quality attributes to higher storage humidity would be influenced by fruit ripening and senescence during shelf life.

Cortex tissue color variables $\left(L^{*}, C^{*}\right.$, and $h^{\text {o }}$ ) were unaffected by high storage humidity during long-term cold storage, but they were significantly influenced during shelf life. These changes may result from accelerated fruit ripening and senescence during shelf life, compared with that occurring during long-term cold storage. The correlation

Table 5. Incidence and severity of shriveling, cracking, and flesh breakdown in 'Royal Gala' apple fruit stored in air at $0.5^{\circ} \mathrm{C}$ for 6 mo. followed by $7 \mathrm{~d}$ at $20^{\circ} \mathrm{C}$.

\begin{tabular}{|c|c|c|c|c|c|c|c|c|c|c|c|c|}
\hline \multirow[b]{3}{*}{ Storage duration } & \multicolumn{4}{|c|}{ Shriveling } & \multicolumn{4}{|c|}{ Cracking } & \multicolumn{4}{|c|}{ Flesh breakdown } \\
\hline & \multicolumn{2}{|c|}{ Incidence $(\%)^{\mathrm{z}}$} & \multicolumn{2}{|c|}{ Severity $(0-5)^{\mathrm{y}}$} & \multicolumn{2}{|c|}{ Incidence $(\%)$} & \multicolumn{2}{|c|}{ Severity $(0-5)$} & \multicolumn{2}{|c|}{ Incidence $(\%)$} & \multicolumn{2}{|c|}{ Severity $(0-5)$} \\
\hline & Control & $\overline{\text { Liner }}$ & Control & $\overline{\text { Liner }}$ & Control & $\overline{\text { Liner }}$ & Control & $\overline{\text { Liner }}$ & Control & $\overline{\text { Liner }}$ & Control & Liner \\
\hline $6 \mathrm{mo}+0 \mathrm{~d}$ & 88.9 & 0.0 & $1.9^{\mathrm{x}}$ & 0.0 & $0.0 \mathrm{~b}$ & $5.6 \mathrm{~b}$ & $0.0 \mathrm{~b}$ & $0.1 \mathrm{~b}$ & 44.4 & 16.7 & 0.5 & 0.3 \\
\hline \multirow[t]{2}{*}{$6 \mathrm{mo} .+7 \mathrm{~d}$} & 77.8 & 0.0 & 1.7 & 0.0 & $0.0 \mathrm{~b}$ & $33.3 \mathrm{a}$ & $0.0 \mathrm{~b}$ & $0.7 \mathrm{a}$ & 100.0 & 88.9 & 2.1 & 2.7 \\
\hline & \multicolumn{4}{|c|}{ Shriveling } & \multicolumn{4}{|c|}{ Cracking } & \multicolumn{4}{|c|}{ Flesh breakdown } \\
\hline Source & \multicolumn{2}{|c|}{ Incidence } & \multicolumn{2}{|c|}{ Severity } & \multicolumn{2}{|c|}{ Incidence } & \multicolumn{2}{|c|}{ Severity } & \multicolumn{2}{|c|}{ Incidence } & \multicolumn{2}{|c|}{ Severity } \\
\hline Liner (L) & \multicolumn{2}{|c|}{$* * * *$} & \multicolumn{2}{|c|}{$* * * *$} & \multicolumn{2}{|c|}{$* *$} & \multicolumn{2}{|c|}{$* *$} & \multicolumn{2}{|c|}{ NS } & \multicolumn{2}{|c|}{ NS } \\
\hline Duration (D) & \multicolumn{2}{|c|}{$* * * *$} & \multicolumn{2}{|c|}{$* * * *$} & \multicolumn{2}{|c|}{ NS } & \multicolumn{2}{|c|}{$*$} & \multicolumn{2}{|c|}{$* * * *$} & \multicolumn{2}{|c|}{$* * * *$} \\
\hline $\mathrm{L} \times \mathrm{D}$ & \multicolumn{2}{|c|}{ NS } & \multicolumn{2}{|c|}{ NS } & \multicolumn{2}{|c|}{$*$} & \multicolumn{2}{|c|}{$*$} & \multicolumn{2}{|c|}{ NS } & \multicolumn{2}{|c|}{ NS } \\
\hline
\end{tabular}

${ }^{\mathrm{z}}$ The incidence of physiological disorders was expressed as the percent of fruit affected $(n=18)$.

${ }^{\mathrm{y}}$ Severity rate of physiological disorders was subjectively evaluated by estimating the percentage of each incidence: $0=0 \%, 1=1 \%$ to $10 \%, 2=11 \%$ to $25 \%, 3=$ $26 \%$ to $50 \%, 4=51 \%$ to $75 \%$, and $5=76 \%$ to $100 \%$.

${ }^{x}$ Means of each category followed by the same letters do not differ significantly. Duncan's multiple range test at $P \leq 0.05$.

Ns $, * * *, * * * *$ Nonsignificant or significant at $P<0.05,0.01$, or 0.0001 , respectively. 
Fresh weight at harvest Circumference at harvest

IEC

Outer cortex firmness (M1)

Inner cortex firmness (M2)

Tissue tensile strength (TTS)

Crispness

Fresh weight loss

Circumference change

Peel $L$ *

Stem-end $L^{*}$

Equator $L^{*}$

Calyx-end $L^{*}$ *

Peel $C$ *

Stem-end $C$ *

Equator $C^{*}$

Calyx-end $C$ *

Peel $h^{\circ}$

Stem-end $h^{\circ}$

Equator $h^{\circ}$

Calyx-end $h^{\circ}$

I AD

Shriveling incidence

Shriveling severity

Cracking incidence

Cracking severity

Diffuse flesh breakdown incidence

Diffuse flesh breakdown severity

$\circ$
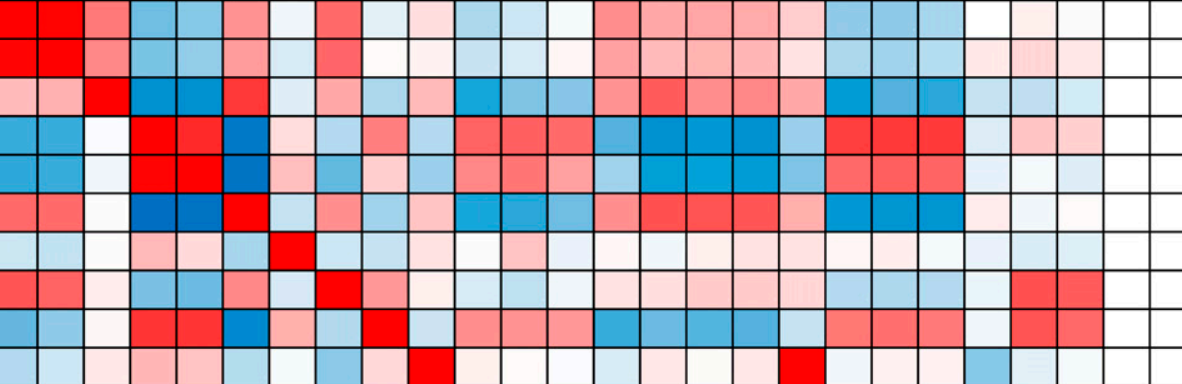

$-$
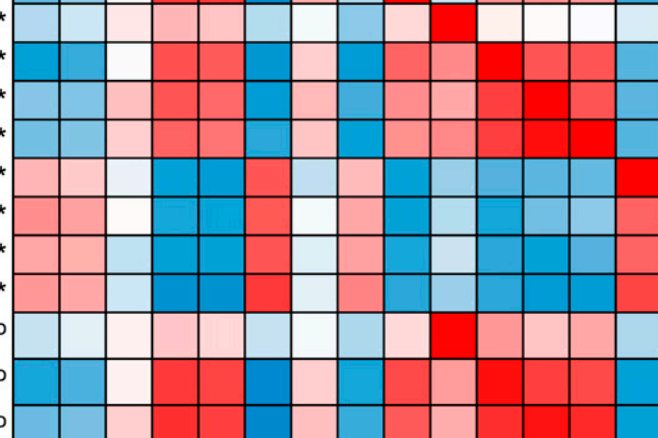

\begin{tabular}{|l|l|l|}
\hline & & \\
\hline & & \\
\hline & & \\
\hline & & \\
\hline & & \\
\hline & & \\
\hline & &
\end{tabular}
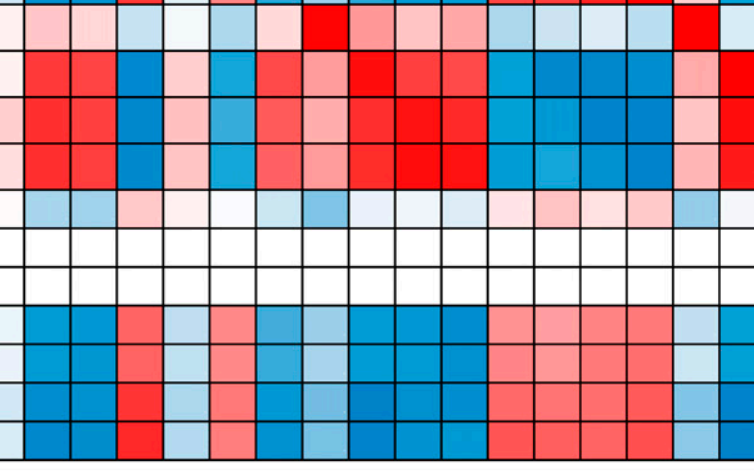
polyethylene liner application or MA packaging (MAP) is an effective technology to maintain fruit quality and freshness along with conventional cold storage (Kim et al., 2018; O'Loughlin, 1975). These single postharvest management technologies would not be sufficient enough to guarantee fruit marketability and consumer acceptability. Use of the combined technologies increases the likelihood of high fruit quality after storage compared with application of each technology alone.

In conclusion, high storage humidity achieved through the use of perforated polyethylene box liners influenced incidence of fruit shriveling and cracking of 'Royal Gala' apples during and after cold storage, respectively. In contrast, flesh breakdown was unaffected by humidity. The loss of fresh weight was reduced by higher storage humidity as was shriveling during storage. High storage humidity resulted in increased fruit circumference and cracking during storage and shelf life. The decrease in flesh firmness in liner fruit may be associated with enhanced fruit ripening under high humidity, although flesh breakdown incidence was not influenced by humidity. In total, high humidity during 'Royal Gala' storage differentially impacts fruit quality and disorder development during and after removal from cold storage.

\section{Literature Cited}

Argenta, L.C., M.J. Vieira, J.G. Krammes, L. Petri, and C. Basso. 2006. AVG and 1-MCP effects on maturity and quality of apple fruit at harvest and after storage. Acta Hort. 727:495-504.

Bai, J.H., E.A. Baldwin, K.L. Goodner, J.P. Mattheis, and J.K. Brecht. 2005. Response of four apple cultivars to 1-methylcyclopropene treatment and controlled atmosphere storage. HortScience 40:1534-1538.

Brookfield, P., P. Murphy, R. Harker, and E. MacRae. 1997. Starch degradation and starch pattern indices; interpretation and relationship to maturity. Postharvest Biol. Technol. 11:2330.

Byers, R.E. 1998. Effects of aminoethoxyvinylglycine (AVG) on preharvest fruit drop, maturity, and cracking of several apple cultivars. J. Tree Fruit Prod. 2:77-97.

Costamagna, F., L. Giordani, G. Costa, and M. Noferini. 2013. Use of AD index to define harvest time and characterize ripening variability at harvest in 'Gala' apple. Acta Hort. 998:117-123.

Fallahi, E., B. Fallahi, and B. Shafii. 2013. Irrigation and rootstock influence on water use, tree growth, yield, and fruit quality at harvest at different ages of trees in 'Pacific Gala' apple. HortScience 48:588-593.

Fan, X., S.M. Blankenship, and J.P. Mattheis. 1999. 1-Methylcyclopropene inhibits apple ripening. J. Amer. Soc. Hort. Sci. 124:690-695.
Harb, J., N.E. Gapper, J.J. Giovannoni, and C.B. Watkins. 2012. Molecular analysis of softening and ethylene synthesis and signaling pathways in a non-softening apple cultivar, 'Honeycrisp' and a rapidly softening cultivar, 'McIntosh'. Postharvest Biol. Technol. 64:94-103.

Ingham, L.M., M.L. Parker, and K.W. Waldron. 1998. Peroxidase: Changes in soluble and bound forms during maturation and ripening of apples. Physiol. Plant. 102:93-100.

Kim, K.-o., J. Yoo, J. Lee, N.M. Win, S. Ryu, J.-S. Han, H.-Y. Jung, M.-G. Choung, Y.-D. Kwon, D.H. Lee, and I.-K. Kang. 2018. Effects of 1methylcyclopropene (1-MCP) and polyethylene (PE) film liner treatments on the fruit quality of cold-stored 'Gamhong' apples. Hort. Environ. Biotechnol. 59:51-57.

Knoche, M. and E. Grimm. 2008. Surface moisture induces microcracks in the cuticle of 'Golden Delicious' apple. HortScience 43:1929-1931.

Knoche, M. and S. Peschel. 2006. Water on the surface aggravates microscopic cracking of the sweet cherry fruit cuticle. J. Amer. Soc. Hort. Sci. 131:192-200

Lee, J., L. Cheng, D.R. Rudell, and C.B. Watkins. 2012. Antioxidant metabolism of 1-methylcyclopropene (1-MCP) treated 'Empire' apples during controlled atmosphere storage. Postharvest Biol. Technol. 65:79-91.

Lee, J., J.P. Mattheis, and D.R. Rudell. 2013. Fruit size affects physiological attributes and storage disorders in cold stored 'Royal Gala' apples. HortScience 48:1518-1524.

Lee, J., J.P. Mattheis, and D.R. Rudell. 2016 Storage temperature and 1-methylcyclopropene treatment affect storage disorders and physiological attributes of 'Royal Gala' apples. HortScience 51:84-93.

Lidster, P.D. 1990. Storage humidity influences fruit quality and permeability to ethane in 'McIntosh' apples stored in diverse controlled atmospheres. J. Amer. Soc. Hort. Sci. 115:94-96.

Ma, Y., X. Lu, J.F. Nock, and C.B. Watkins. 2015. Peroxidase and polyphenoloxidase activities in relation to flesh browning of stem-end and calyx-end tissues of 'Empire' apples during controlled atmosphere storage. Postharvest Biol. Technol. 108:1-7.

Maguire, K.M., A. Lang, N.H. Banks, A. Hall, D. Hopcroft, and R. Bennett. 1999. Relationship between water vapour permeance of apples and micro-cracking of the cuticle. Postharvest Biol. Technol. 17:89-96.

Mattheis, J.P. 2008. How 1-methylcyclopropene has altered the Washington state apple industry. HortScience 43:99-101.

Mattheis, J.P. 2017. Controlled atmosphere $\mathrm{pO}_{2}$ alters ripening dynamics of 1-MCP treated 'd'Anjou' pear (Pyrus communis L.) fruit. HortScience 52:1385-1389.

McGuire, R.G. 1992. Reporting of objective color measurements. HortScience 27:1254-1255.

O'Loughlin, J.B. 1975. The influence of some packaging and post-harvest treatments on the incidence of ripe spot in 'Golden Delicious' and 'Crofton' apples. Sci. Hort. 3:75-81.

Opara, L.U., A.J. Hodson, and C.J. Studman. 2000. Stem-end splitting and internal ring-cracking of 'Gala' apples as influenced by orchard man- agement practices. J. Hort. Sci. Biotechnol. 75:465-469.

Opara, L.U., C.J. Studman, and N.H. Banks. 1997a. Fruit skin splitting and cracking. Hort. Rev. 19:217-262.

Opara, L.U., C.J. Studman, and N.H. Banks. 1997 b. Physico-mechanical properties of 'Gala' apples and stem-end splitting as influenced by orchard management practices and harvest date. J. Agr. Eng. Res. 68:139-146.

Padilla-Zakour, O.I., K.S. Tandon, and J.M. Wargo. 2004. Quality of modified atmosphere packaged 'Hedelfingen' and 'Lapins' sweet cherries. HortTechnology 14:331-337.

Perring, M.A. 1984. Lenticel blotch pit, watercore, splitting and cracking in relation to calcium concentration in the apple fruit. J. Sci. Food Agr. 35:1165-1173.

Prange, R.K., J.M. DeLong, and P.A. Harrison. 2001. Storage humidity and post-storage handling temperature affect bruising and other apple quality characteristics. Acta Hort. 553:717-720.

Richard-Forget, F.C. and F.A. Gauillard. 1997. Oxidation of chlorogenic acid, catechins, and 4-methylcatechol in model solutions by combinations of pear (Pyrus communis cv. Williams) polyphenol oxidase and peroxidase: A possible involvement of peroxidase in enzymatic browning. J. Agr. Food Chem. 45:24722476.

Róth, E., E. Kovács, M.L.A.T.M. Hertog, E. Vanstreels, and B. Nicolaï. 2005. Relationship between physical and biochemical parameters in apple softening. Acta Hort. 682:573-578.

Thompson, A.K., B.O. Been, and C. Perkins. 1974. Effects of humidity on ripening of plantain bananas. Experientia 30:35-36.

Tu, K., B. Nicolaï, and J. De Baerdemaeker. 2000. Effects of relative humidity on apple quality under simulated shelf temperature storage. Sci. Hort. 85:217-229.

Wargo, J.M. and C.B. Watkins. 2004. Maturity and storage quality of 'Honeycrisp' apples. HortTechnology 14:496-499.

Watkins, C.B., J.F. Nock, and B.D. Whitaker. 2000. Responses of early, mid and late season apple cultivars to postharvest application of 1methylcyclopropene (1-MCP) under air and controlled atmosphere storage conditions. Postharvest Biol. Technol. 19:17-32.

Watkins, C.B. and C.J. Thompson. 1992. An evaluation of microperforated polyethylene film bags for storage of 'Cox's Orange Pippin' apples. Postharvest Biol. Technol. 2:89-100.

Weber, A., A. Brackmann, F.R. Thewes, V. Both, R.O. Anese, and M.R.W. Schorr. 2012. Relative humidity and its interaction with the storage temperature of 'Gala' apples and mutants. Cienc. Rural 42:2159-2165.

Winkler, A., E. Grimm, M. Knoche, J. Lindstaedt, and D. Köpcke. 2014. Late-season surface water induces skin spot in apple. HortScience 49:1324-1327.

Yoo, J., J. Lee, S.-I. Kwon, K.H. Chung, D.H. Lee, I.M. Choi, J.P. Mattheis, and I.-K. Kang. 2016. Differences in ethylene and fruit quality attributes during storage in new apple cultivars. Hort. Sci. Technol. 34:257-268. 